International Scientific Journal Theoretical \& Applied Science

p-ISSN: 2308-4944 (print)

e-ISSN: 2409-0085 (online)

Year: 2016

Issue: 3

Volume: 35

Published: $30.03 .2016 \quad$ http://T-Science.org
Elnur Latif oglu Hasanov Corresponding member of International Academy of Theoretical and Applied Sciences, Ph.D., Senior specialist of Ganja Department Azerbaijan National Academy of Sciences, Ganja, Azerbaijan 1-hasan@hotmail.com

SECTION 12. Geology. Anthropology.

Archaeology.

\title{
ACADEMIC PROBLEMS OF RESEARCH OF DECORATIVE-APPLIED ARTS AS THE HISTORIC-SOCIOLOGICAL FACTORS OF CIVILIZATION CULTURE (ON THE BASIS OF MATERIALS OF GANJA CITY)
}

Abstract: Have been investigated the basic features of local decorative-applied arts of Ganja from the point of research of civilization culture on the basis of different scientific sources and innovative methods.

Key words: Azerbaijan, Ganja, historical-ethnographic research, decorative-applied arts.

Language: English

Citation: Hasanov EL (2016) ACADEMIC PROBLEMS OF RESEARCH OF DECORATIVE-APPLIED ARTS AS THE HISTORIC-SOCIOLOGICAL FACTORS OF CIVILIZATION CULTURE (ON THE BASIS OF MATERIALS OF GANJA CITY). ISJ Theoretical \& Applied Science, 03 (35): 7-16.

Soi: http://s-o-i.org/1.1/TAS-03-35-2 Doi: crossef http://dx.doi.org/10.15863/TAS.2016.03.35.2

\section{Introduction}

Ganja city is situated on the west of Azerbaijan and Ganja is known as a motherland of such famous persons. Up to the end of Middle Ages, Ganja was one of the most resplendent and well-known scientific and cultural centers of the East throwing down a challenge to Europe from both the economic and cultural point of view. Medieval historians called Ganja the last greatest urban and frontier point ("sarhad dar al-mulku") in the North of the Moslem world.

The carried archeological digs and historical sources refer the history of Ganja to the VII century B.C. Since the X-XI centuries A.D., the glory of Ganja, the city outliving the period of its economic and cultural development, flourishing and becoming mighty, spread from Kiev Russia to India, China and the whole East. The high-level organization of the defence system of Ganja with 300 thousand people of its population is a proof of rise of a level of its development.

As the Arabian Caliphate was establishing, it subjected the Southern Caucasus to its influence. In order to rule over regions, the Caliphate used the Emirate system. In various periods, governors were called by various titles. The Arabian Caliphate called a governor as Amir. In order to rule Tiflis and surroundings, another emirate was established.
Historical facts show that exactly in this area in Eastern Georgia, majority of the population consisted of Azeri Turks. One of our most ancient sources "Kitabi - Dada Gorgud" proves this fact.

At the same time, Tiflis Moslem Emirate kept close relations with the State of the Shaddadis existed in Azerbaijan at that time.

Being a Turkish-Islamic Union, the State of the Shaddadis (an ancient Azeri state) including the Seljugs (a Central Asian empire), prevented the conquest of Western Azerbaijan lands by Georgia and its protector - Byzantium for a long time.

In 1054, after conquering Azerbaijan, the Seljugs feudalized both the State of the Ravvadis and the State of the Shaddadis. Ganja also became a vassal of the Seljugs. The well-known Ganja Gate was prepared in the period when the State of the Shaddadis was a vassal of the Seljugs. Afterwards, as a result of the collapse of the Caliphate, the TiflisMoslem Emirate became independent.

Development of some local handicraft branches in this city historically offered necessary facilities for progress of civilization culture:

\section{Pottery and brick production}

The formation of pottery on the territory of ancient Ganja is concern to the stages of ancient history. Basis on research works carried out by the various persons in XIX century and expertsarcheologists at the beginning of XX century in old 
ruins of the city and surrounding areas there were found different samples of pottery.

First of all, there have been discovered, that initial ceramic production in Ganja and its surrounding regions are belong to the VIII-VII millennium BC. From the history point of view, these ancient clay vessels, belonging to the Neolithic stage, are differing from the pottery samples of the neighboring ethnic in number characteristics.

These differences are seen in preparing technology, also in the area of external surface decoration.

From the construction point of view, samples of pottery, that concern to Antique period, also to the period of Hellenism in Ganja, differed in various forms:

1. Pictorial vases

2. Ceramic figures

3. Connected dishes

Pottery dishes, that concern to the first stages of Middle Ages of Ganja, are differing from the ceramic samples of Antique period in two features:

1) On shape.

2) For preparing techniques.

Potter's products of the Early Middle Ages of Ganja and its regions for their technical characteristic are divided into 2 major groups:

I. Glazed ceramic products.

II. Unglazed ceramic products

The main types of samples of ancient clay toys in Ganja regions are the follows:

1. Rattle.

2. Zoomorphic figures.

3. Toy dishes.

The end of middle Ages and New Period. In this historical period in Ganja and its regions ceramic has following kinds:

1. Building ceramic materials.

2. Unglazed ceramic products.

3. Glazed ceramic products.

Construction ceramics: For Middle Ages and New period among pottery products of Ganja ceramic samples as clay construction materials have great importance. First of all, glazed bricks that used in construction of most buildings in the XVII-XVIII centuries, and also in great monuments and the main construction material- air-dried bricks, attracted attention. During this period, using of baked brick has been widened and their standard sizes were as follows:

\section{$25 \times 24 \times 5 \mathrm{~cm}$;}

$25 \times 25 \times 5 \mathrm{~cm}$.

In addition to the found samples in residential areas as a result of archaeological excavations, also were found a lot of brick spoilages. According to such kind mass finding of brick spoilages, we can make the conclusion, that the bricks used in construction of buildings in Ganja, were wares of local production [8-12].
II. Bone processing. In middle ages in spheres of gentle and applied art, Ganja of inhabitants of territory, in agriculture life bone was widely applied. Bone products, raw materials that found during investigations in and around Ganja prove, that time bone processing separated from other spheres of craftsmanship. Osteology analysis prove, that most of samples are prepared from the bone of bull, caw, deer among big horde animals and sheep, goat, boar among little horde animals.

1. Only deeding investigations in Mingechaurs there were found a lot of samples of combs, agriculture instruments, art and other bane things. Such kind of bone samples also were found in monument complexes territory of Injachay and Kerpicli in Goranboy region during excavation. Art samples and dice for playing nard, found in territory Shatal, also attracts our attention. These samples of art make more ancient history of city culture of Azerbaijan and in whole play nard. There were found knife handles, rare geometrical decorations, samples of pipe and other instruments here.

2. During excavations there was found bone products that used as raw materials and cutting with pipe. In XI- XIII centuries this sphere of art was developing mostly. This thought is proved with a lot of bone and horn, found in zone of excavation. This period from bone there were prepared buttons, knifes and etc. Found during archeological excavations and used in wooden treatment and knife, showed that at the beginning of XI - XIII in and around Ganja this sphere of craftsmanship in exist. Bone boards with circular surface molding decoration decoration were found in Mingechaur, in Khogali barrow № 2, Sarichoban, Borsunlu and others. Monument, that including to Borsunlu Complex is finishing with small wheel desk from bone and two omlets, prepared from teeth of boar. In this period also were prepared such kind of agriculture instruments as wood shovel, rake and etc. But they didn't reach nowadays [5].

\section{Materials and Methods}

Masonry and stone treatment: Ganja and its surrounded territory are also rich with different stones. Presentation of white and in mountain and Aran Karabakh and also lime, traverse and marble building stones in and around Ganja, pure white, a lot of colored agates, chalcedony, veil, ametist, obsidian, agates, crystal and other kind of rare colored stones in the river basins of Shahdaq Kecheldaq, and other territories created favorable ground for developing in this ancient country from ancient times stone cutting, stone grind, stone polishing and for building great 
modern , columned, arched, circled and fourcornered buildings here.

Similar with it, but founding stone potter with simple surface in grave kurgan № 12 also proves it. Founding such kind of things on Uzerlik tepe also proves our thoughts.

Some at the materials consist of mace stone. They coincidence to height grave borrow № 1. Mace stone have spherical form. They are similar with materials in Middle Bronze period. Founded in ruin graves cast -ironed boiler and painted spear with thin breath and length are similar for monuments of that period of Azerbaijan (Kizilveng, Aznabyurd and etc.) In Complex Borsunlu there are grinding stones with hole for hanging and mace plead, prepared from grey marble in form of pear. Borsunlu mace is differing from all other monument's mace of Azerbaijan. Maces in form of pear mostly we can see in complexes in the North Iran and South Turkmenistan, that concern to the second half of second thousand BC [6].

Among archaeological equipment there have been found two big boards from stone "camel eyes". Base - columns, capitals, that are symbols of irreplaceable art, part of columns, different man monuments, masonry art symbols, that have Ganja, agriculture and religious meaning, especially grave monuments and phalluses, collections of different colored (red, brown, black, grey and other rare colored) stamps and symbols of decorations, that were found in Azerbaijan during archeological investigations prove it.

These rare discovers in and around Ganja are known from the archaeological investigations in ancient cultural, art and trade centers of Azerbaijan, such as Mingachevir, Barda, Baku, Smamakha, Qabala, Ganja, Shatal, Beylagan, Shabran, Khazakh, Qakh, Quba, Qushchu, Shargah, Torpaggala and other archaeological and architecture complexes. The best samples of monuments, that concern to stone treatment are consists of column props, mill and gridding stones. In whole there were founded in and around Ganja a lot of samples, that concern to X century. They are consisting of stone figure, mills and column props. But stone equipment, found in Ganja, Shamkir and Shatal prepared from mill and candlestick. Mill is usually prepared from volcanic, quartz, limestone and basalt. They used for grinding seed, millet, slot and for other aims [7].

We meet mostly mill stones, scales and pumice stone in stone treatment. At the same time there were use $3 \mathrm{~d}$ hewed stones for decorating buildings. In this period there were prepared decorations from precious stone.

Different colored stone samples and agreements, that found in monuments of Shamakhi, Barda, Mingechaur, Qakh, Ismayilli, Quba and other regions are the best symbols of art, painting, religion, heroism and art themes of Azerbaijan. Such kind of fleece monuments have been found in village Gurzalilar of Goranboy region, in Goygol, Dashkesan and Samuch and investigated here. It is interesting, that from the workshop of these monuments have been found instruments of masters and samples of raw-materials. All these aspects show, that inhabitant of Middle Ages in and around Ganja from the ancient period did masonry, gridding and stone treatment. This sphere of art in developed middle Ages could be in high level.

And rare magnificent architectural monuments in and around Ganja that stay till nowadays, prove it.

IV. Silkworm breeding: Traditional textile of art of silk weaving products has a special place in Ganja. In the city formed two main method of silk treatment:

1. Spinning

2. Winding

From the point of view silkworm breeding development and its preparing technology there were two main forms of production: so-called raw silk weaving and felt weaving .In this important technological processes it has such kind of production stages as cocoon opening, silk initial processing ,preparing of raw silk, weaving technology, painting and decoration.

In the ancient Ganja during the stage of the Middle Ages the great progress of silkworm was represented by raw silk weaving. For this reason, on the basis of local traditions production of delicate silk textiles from raw silk.

There were made such kind of important samples of art as atlas and kelaqai (silk kerchief). We must pay attention to the moment that differs from the other silk fabrics, kelaqai was prepared by specialists. But distinctly of production of raw silk, that was city silkworm breeding and was man activity, felt production was woman work.

V. Saddle-making: In Ganja, that know as the ancient cultural center, the saddle-making handicraft differed from others with rich old traditions. First time preparation of the vehicles was house profession. But afterwards saddle preparation needed of qualified skilled masters, so a new type of art saddle-making, started to form.

Historically the traditional art of saddle-making in Ganja developed in direction of cargo and passenger saddle making. The art of saddle-making within the local saddle-types and their components were determined on a specialization. The production of cargo or pack -saddle a rule was engaged by packsaddle maker. For this reason, in most cases, the profession was called trade of pack-saddle maker [8].

Afterwards military, economic and transportation significance of hoarse was decrease, the demand for goods of saddle-making also was decrease. The reason of primitive saddle-making decreasing was wide sale of cheaper factory products. 
History and art of Azerbaijan people as rich and colorful as its nature. On decorations of this descriptive art are reflected spiritual world, living style, customs and traditions of our nation. These pearls of art on material preparing and processing techniques are divided into different kinds. Among these types of craft metal treatment is mostly developed and has ancient history. Abundance of local raw materials created favorable conditions for development of metal treatment from ancient times. In general, in the third millennium BC there was high culture of the Bronze Age in our country, and in the first millennium transition period from Bronze Age to Iron Age began. In that period in Azerbaijan there were appeared several branches of metallurgy treatment. Jewelries, daggers, arms, copper products and other samples of art have been treated so refined, that in nowadays they are protected as very valuable exhibits in famous museums in such cities, as Paris, London, Brussels, Istanbul, Tehran and other cities.

VI. Glass production: There is no any source about glass production in and around Ganja. The majority of archaeologists agreed with the idea, that the homeland of glass production is ancient Egypt, but the famous English archaeologist, Egyptologist Petri Flinders thought, that it could be Mesopotamia or the Caucasus. Taking into account that cobalt, used in glass coloring wasn't in Egypt, the scientists thought that, it could be in the Caucasus, also in Dashkesan.

Samples of glass decorations, of BC, we met in the patterns of Ganjachay, Mingechevir, Xachbulaq and others. In these areas, the first centuries BC were found in samples of the glass plate.

The majority of containers and the analysis based on graphical elements of the Roman scholars came to the opinion that the samples of the same scale as the Roman Empire through trade.

There are more than 2000 beads in complex materials. Colored beads have prepared of different types products. Mostly distinguish beads that prepared from blue green and grey paste. A group of beads made of bone and antimony.

A part of the hanging beads were prepared from cockleshells "Nassagibbosula" and "Suraeva Moneta». According to expert's thoughts, such kind of cockleshell that widely spared in the Indian and Pacific Ocean, also the Eastern Mediterranean region were put to Azerbaijan with economic relations.

Among the materials of Borsunlu Complex are differ with number of beats in majority and form.

In III-V centuries, the local craftsmen themselves also became to produce better-designed containers. Among the local clay and glass utensils that found in and around Ganja there were big similarity in the form and also in the decoration.

All the glass dishes found in and around Ganja are similar with the local clays on decoration of that period. Glass dishes were containing of Iron, cobalt, magnesium and other elements, that were specific elements for Ganja and its surroundings.

The development history of this sphere of craftsmanship can be determined only through archaeological research. In general, information about the development of this sphere of was found in 1959-1960 years, glass products in and around Ganja was obtained only at the end of the twentieth century.

Results of archaeological excavations in the territory of Azerbaijan and research show that in the preparation of glass utensils were two technical methods: casting method and the method of blowing. The first of these methods is more ancient, but in the Early Middle Ages and Middle Ages were used both of them.

Produced glass alloys were transparent colored. By the addition of dusts of various metals in glass alloys people got colored glasses. We can see also to get her with different tinted green glasses also parts of blue, black and pink colored glass dish in sections of IX-X century in Shatal and Ganja. In IX-X centuries appeared dishes, that had handle and spout .

Glass products, obtained in Ganja and Shatal in the IX-X centuries, find their similarities in dwelling places of the Middle Ages in Barda, Beylagan, Mingechevir, also in the obtained materials of the neighboring republics of the same period.

Among decorations of that period yellow, white and red beads of round and plain form are met mostly. At the beginning of X-XIII centuries development of production of glass in and around Ganja characterized by improvement from the technology point of view.

Archaeological researches show, that outside of the cities in the VIII-IX centuries, also big settlements were established. This is often due to density in cities.

From the point of view silkworm breeding development and its preparing technology there were two main forms of production: so-called raw silk weaving and felt weaving. In this important technological processes it has such kind of production stages as cocoon opening, silk initial processing ,preparing of raw silk, weaving technology, painting and decoration. In the ancient Ganja during the stage of the Middle Ages the great progress of silkworm was represented by raw silk weaving. For this reason, on the basis of local traditions production of delicate silk textiles from raw silk .There were made such kind of important samples of art as atlas and kelaqai (silk kerchief). We must pay attention to the moment that differs from the other silk fabrics, kelaqai was prepared by specialists. But distinctly of production of raw silk that was city silkworm breeding and was man activity, felt production was woman work. In Ganja, that know as the ancient cultural center, the saddlemaking handicraft differed from others with rich old traditions. First time preparation of the vehicles was 
house profession. But afterwards saddle preparation needed of qualified skilled masters, so a new type of art saddle-making, started to form. Historically the traditional art of saddle-making in Ganja developed in direction of cargo and passenger saddle making. The art of saddle-making within the local saddletypes and their components were determined on a specialization. The production of cargo or pack saddle a rule was engaged by pack-saddle maker. For this reason, in most cases, the profession was called trade of pack-saddle maker.

Afterwards military, economic and transportation significance of hourse was decrease, the demand for goods of saddle-making also was decrease. The reason of primitive saddle-making decreasing was wide sale of cheaper factory products.

Ganja city, which located on an altitude of 400450 meters above sea level, is situated on the west of Azerbaijan, 375-kms to the west from the capital city Baku, on Ganja-Kazakh plain, that located in the Kura - Araz lowland, at the foot of the Lesser Caucasus on the north-east. Ganja is situated in the Western part of Azerbaijan and has more than 3000 years old. During centuries in this ancient cultural and scientific center developed different branches of craftsmanship. Scientific and archaeological researches have proved that Ganja was cradle of science and culture not only of Azerbaijan, but also of the whole East.

Ganjabasar is one of the richest areas from archaeological point of view. As a result of archaeological investigations here were found samples of material culture that concerned to the stages of different history period. Today most of them are kept in various museums of the world.

The flint tools, that found in Gillikdag workshop and camp around Ganja, ladle, that were found by a prominent Azerbaijani archaeologist Isag Jafarzadeh, give the reason to say, that people, who lived in this area in VII - VI millennium BC were the founders of the Late Stone Age culture. Archaeological investigations prove that in this period the main population of this region had sedentary lifestyle and were engaged with farming.

VII. Wood treatment and trade of ornamentals: In the territory of Azerbaijan the oldest samples of wood treatment were found in the territory of ancient Ganja. Around Ganja area - in the region of Lake Goy-gol in the IV-III millennium BC have been discovered wooden thicker board, also wooden sugar bowl, that concern to the end of the II millennium $\mathrm{BC}$, found in Mingechevir pitcher grave are material evidences of science thoughts.

Along with the works and notes of medieval authors and travelers, a lot of material samples, found in the territory of ancient Ganja, also found in Mingechevir and concern to Middle Ages trough, ladle, wooden threshing board, shows that in Ganja wood treatment and sculptor art have a rich tradition.

Wood treatment products historically have been represented in various fields of social and cultural life in Ganja:

1. Kitchen appliances: trough, quadruped, rolling-pin, mortar and pestle, ladle, spoon, trough.

Ganja kitchen with its national characteristics is differs from other regions of Azerbaijan. The cooked dishes, prepared sweets, sherbet (sweet drink) are differing for their tasty and manufacturing technology. Ganja has a positive impact on national food composition in the human body, is the health service [11].

In Ganja relationship ties are very strong. It is the tradition of Ganja people to often visit relatives, and to share their sadness and happiness. In whole Ganja's traditions are leading to spiritual pureness, they are collection of the universe laws to perfection, way of nation.

Until the middle of the twentieth century, the city was ruled by elders, elders played a role of bridge between the people and official government agencies. The most important of customs and traditions is forgiveness. During transaction people give each other forgiveness. If the patient going to die also people give him forgiveness and receive from him forgiveness. So they say: "without forgiveness will not be blessed." [3; 4].

Neighborly relations are kept and preserved strictly in Ganja. People don't buy a house, before they interesting in neighbor's character. They say: "Don't buy house, buy neighbor; "the nearest neighbor to distant relation."

In Ganja relationship ties are very strong. It is the tradition of Ganja people to often visit relatives, and to share their sadness and happiness. "If also relative will eat each other's meat, they won't dispose each other's bone," - they said.

It is important to know that one of the areas of initially appeared human civilization was an integral part of Azerbaijan, the historical land of the city Ganja. Scientific and archaeological researches have proved that Ganja was cradle of science and culture not only of Azerbaijan, but also of the whole East.

Ganjabasar is one of the richest areas from archaeological point of view. As a result of archaeological investigations here were found samples of material culture that concerned to the stages of different history period. Today most of them are kept in various museums of the world.

The flint tools, that found in Gillikdag workshop and camp around Ganja, ladle, that were found here, give the reason to say, that people, who lived in this area in VII - VI millennium BC were the founders of the Late Stone Age culture.

Archaeological investigations prove that in this period the main population of this region had sedentary lifestyle and were engaged with farming. 
In $\mathrm{V}$ millennium BC in Ganja region all known to us domestic animals were domesticated.This fact is approved with osteology remainders that were found during archaeological excavations.

The anonymous author of the article "Russian city" gave the schedule indicating the date of cities of the South Caucasus, also of Azerbaijan. And here he matched, that Ganja was founded in II century BC IV centuries.

The same words, that match, that Ganja is older than Barda and Beylagan prove Qagemeyster's information and conception, that says " At a short distance from Barda another city was also flowering, which at the time of destruction substituted it. It was Ganja city. Their origin, probably, was the same ... ".

The majority of historical monuments, that are demonstrate the 4000 thousand year history of Ganja, which is the national wealth of our people, today gain unique place in the expositions of world's museums. In state and private museums of Metropolis, Munich, Berlin, Hamburg, Louvre, Paris, Moscow, St. Petersburg and other cities rare and valuable exhibits, that concern to the history of ancient Ganja are preserved.

Ganja city that located on an altitude of 400450 meters above sea level is situated on the west of Azerbaijan, 375-kms to the west from the capital city Baku, on Ganja-Kazakh plain, that located in the Kura - Araz lowland, at the foot of the Lesser Caucasus on the north-east.

\section{Most of}

geographical conditions, plenty water of rivers, fertile land, rich ore deposit, fuel, wood materials used for construction and craftsmanship, colored plants for getting color and natural caves allowed the first people to live in this area in the Late Stone Age.

Ganja, that has changed its location at least 4 times since its establishment, is located in a favorable position from the strategic point of view.

That why it always has been the center of attention of foreigners. Ganja, that was the victim of a terrible earthquake many times, also was the subject of attacks of Mongols, Kharezms, Georgians, Arabs, Russians and other invaders. Ganja has turned to the arena of war damage of different countries of the world .But in spite of it didn't shaken, and using the genetic power revived and developed, and rose to the level of great cities. Protection of independence and state traditions by Ganja's people under Javad Khan's direction and showing an example of heroism against aggressive Tsarist Russia is forming a glorious page of our history.

In Ganja people mostly pay attention to realgeneration, family. If someone wants to marriage his son or daughter, he interests with generation and family of the opposite side.

Sometimes, when families can't pliable with each other, they say: "Our bone connected with their bone." When they speak about bone, they mean father's line; about milk they mean mother's line. In this way Ganja people were able to kept and preserved pureness of generation. Ganja people are very strong in friendship. Also they can die for friend. Friend will pay all the needs of friend, will be his back-support. The equality in friendship is very important: «Show me your friend, and I will say you who you are. Ganja is famous for its hospitality. Most traditions of meeting guest are followed today.

For guest in Ganja, as a rule, separated a special room - sitting room. This room is decorated with expensive carpets, put delicate dishes, silk bedding for the guest. For breakfast of guest put cream with honey. For dinner and supper are prepared delicious foods. Among them a plov seasoning with meat and lamb meat kebab are take a special place. Ganja people put all kinds of table-blessing for guest. In addition they tell to guest kind words, and take to interesting places, worth visiting and pilgrimages. They never ask, when the guest will return.

This act shall be considered as disrespect. "The guest is God's guest ", - say Ganja people and meet the guest with honor, various gifts and send with respect. One of the more preserved customs and traditions of Ganja, that has deep historical roots, is the tradition of the wedding. Wedding, that full of rites and ceremonies is a whole holiday of elin. In this case, the close people, relatives are more active [5].

The wedding took place in stages girl for so long everyone is happy. In the past there were various games, competitions and races in Ganja weddings. Now, some of these wedding are traditions are forgotten. Ganja didn't have girl's wedding. Instead of it, there was "Parchakesdi" ("piece cutting") ceremony. "Parchakesdi" was replaced girl's wedding. And now the tradition of cutting the girl's wedding piece is also preserved. Such traditions as "khinayakhdı", "uchashi", "evgordu" are live on nowadays. As all the parts of the world, mournful funeral ceremonies in Ganja hold very sadly. Relatives of dead man put on black clothes, don't go to parties for a while, and don't listen to music. The first day of man's dead, third day, seventh day, 40th day and "adna" days (Thursdays) funeral ceremony is continue. Ganja's funeral ceremonies can't be without rose water. Good smell of rose water eliminates man's pain. When people live funeral ceremony, they give condolences to the owner of mourning. Also, it is necessary to teach the local national holiday's traditions in Ganja. Khidir Nabi and Novruz holiday in Ganja are celebrated ceremonial. In holiday of Khidir Nabi people roast wheat, and set Khidir's table.

Then the flour of roasted wheat people put to secret room. Khidir Nabi comes at night, and put on finger to flour of roasted wheat. In house, which Khidir entered, there will be abundance. 
Ganja people are going to celebrate Novruz holiday within a month. They keep in order house a, different kind of sweets are prepared. Among them Ganja's pakhlava take more attention. Pakhlava, which consists of nine layers, decorates tables. Eggs are colored; "nazik" (sweet bread) are cooked. Bearing a grudge are reconciled, people visit sick, lonely relatives. People skipped over the bonfire, goes to ear fortune telling, look fortunes in the water, visit and take holiday gifts branded girls, sick, elderly people [1-3].

Ganja pakhlava can be cooked with nuts and almond. Contents of dough: flour, egg, sour cream, rose water. As usual pakhlava contains of twelve layers. We make 2 thins, in interm we cover it with oil then on each layer we put sugar powder, nuts and add stuffing which is made of cardamom.

Then we colour our dough with liquid made of saffron. After it we cut our dough in the shape of rhombic and cover it with nuts and other things as you like. Corners we decorate with khash-khash. Bakhlava is cooked in copper trays on the coal. On the cover we use syrup (honey, sugar powder).

Irishte pakhlava is made of wheat flour and starch. With rose water liquid dough is made in round figures. As one layer Irishte is put, stuffing which is made of roasted nuts, sugar, cardamom is covered in thick form. Then irishte is put. We make it three times. Upper layer is cut in the form of rhombic. The rhombic shape is decorated on the cover of irishtebakhlava from four sides with saffron, in the middle we add clove.

Zilviya. Ingredients: flour, egg oil, yoghurt, starch. Liquid dough is made of these ingredients. Liquid dough with funnel in rounds is poured into vegetable oil. As it cooked in hot way we put dough into sugar and syrup in water. After 5 minutes the dough is extracted. As we represent the sun we use golden or red colours on liquid dough.

Nazik. Ingredients:flour, sugar, saffron, butter, milk, egg, salt, yeast and ground coriander seeds, with these ingredients dough is made. We make dough balls in the shape of bread. Then we can cover it with almond-shaped button, dehreburni, nebati, and also draw the surface of dough balls with patterns in the shape of geometric figures of national ornaments. At last we cover the surface with egg and sow with khash-khash, after that the dough is cooked in the oven.

Shekerbura. Ingredients: flour, butter, egg, milk, rose water, yeast and salt. With these ingredients dough is made. Nuts in sugar powder, nuts or almond and ground cardamom are used for stuffing. Dough is cut in small pats.On each pat we use stuffing then wrap them up. After the corners are wraped up the surface of shekerbura is decorated with tweezers. We cook shekerbura within ten minutes in hot oven.

Kete. Ingredients: flour,butter, egg, yoghurt and aromatize things. With these ingerdients we make dough. For stuffing it can be used butter, flour, sugar powder. Adding the stuffing into the dough in the form of roll we wrap it up and with special tool for these roll we cut the dough in rhombic forms. For the surface yolk can be used. Then it is cooked inoven [2-4].

2. Transport means: sleigh, car, and ski.

3. Weaving tools: comb, face.

4. Household tools: harrow, wooden plow,threshing board, spade, wooden shouvel, pitchfork, rake.

5. Musical instruments: saz, ud, tar, chamahcha, tambourine, drum.

Along with the mosque Cuma (Shah Abbash),that constructed in 1606, local samples of trade ornamentals , that built in Sheikh Javad Khan Street, that have 3 century history and was built in the nineteenth century in building of Sheikh Nizami Ganjavi's (1141-1209) representatives Sheikhzamanlylars property and, that was restored in 2011, are attractive especial attention [4-11].

\section{Conclusion}

The craftsmanship of carpet-making is one of the important cultural achievements of the Eastern people in Azerbaijan production of carpets appeared during I millennium BC. But carpet-making in the first period of Middle Ages has turned to the independent sphere of craft. In Ganja, that has minimum 4000 years history, production of carpets differed with quickly development.

In this ancient city, that is native land of great Azerbaijani poet and thinker Sheikh Nizami Ganjavi, were weaved very uncial, inimitable kinds of carpet. In Ganja, that has rich traditions, were prepared carpets with various characteristics. For this reason one of Azerbaijani carpet groups are Ganja carpets or (Ganja-Kazakh carpets).

Pay attention that in Ganja namely local kinds of carpets-palaz (carpets without of pile) are weaved [1]. These carpets that are producing by local inhabitants are differing with specific handicraft features:

1. Ganja carpets are differing with pile.

2. Thickness indicators of such kind of carpets with small number attract attention $(25 \times 30)$.

3. Composition is more distinct and simple.

4. Most of ornamental patterns have geometrical features.

5. In coloring carpet samples were used bright colors.

6. Local carpet masters skillfully used buta's amatively patterns [2].

The size of Ganja's carpets begins from 3 square meters to 10 square meters. There are 2 important carpets groups exist:

1. Ornamental carpets.

2. Carpets with a plot. 
Majority of local wool products, richness of natural colors and existence professional carpetmaking women made for quick development carpet making craftsmanship in Ganja and in its surround territories.

Just only in 1845 year there were produced 2969 carpets in Ganja. Among them products of 1784 manats have been exported. Also, from Ganja province there were exported 23 thousand pod in 1886,30 thousand 275 pod in 1889,33 thousand 156 pod in 1893, and 37 thousand 228 pod in 1913 carpets by railway. One part of these qualitative Ganja carpets has been transported with Batumi part top Turkey to Istanbul, and from there to West Europe and North America [3].

In whole at the beginning of IX- XX century the quality of carpet craftsmen were more than $\mathrm{XX}$ thousand. At the result of it during a lot of years were prepared such kind of qualities carpets as "Kohne Ganja" ("Old Ganja"), "Phahrali", "Chiraqli", "Chayli", "Samukh", "Zeyva", "Sarisi”,"Shadilli".

In this period in Ganja were produced as carpet with pile, also carpets without pile.

Such kind of carpets without pile as phalas, kilim, holdall, bead, verni, sumach, heybe, carpet bag were different with qualities and colored ornamental elements.

Especially we must say that Ganja carpets have always been valued for its quality and art characteristics. As the result of in IX - XX centuries most of Ganja carpets were showed in world in fluent exhibition. In 1850, 1852 and 1912 years in Tbilisi, in 1896 - in Nijni Novgorod, in 1900 year in Paris, in 1911 year in Turn Ganja carpets were showed and highly in international exhibition. Nowadays, Ganja's carpets are kept in authoritative museums of world, and also in collection of different people. The studying of Ganja's carpets for art characteristics quality form science point of view is very important for investigation heritage of world culture [4].

Metal treatment: (coppersmith, blacksmith, arm craft, goldsmith, currier, hating, felting, cobbling)

History and art of Azerbaijan people as rich and colorful as its nature. On decorations of this descriptive art are reflected spiritual world, living style, customs and traditions of our nation. These pearls of art on material preparing and processing techniques are divided into different kinds. Among these types of craft metal treatment is mostly developed and has ancient history.

Abundance of local raw materials created favorable conditions for development of metal treatment from ancient times. In general, in the third millennium $\mathrm{BC}$ there was high culture of the Bronze Age in our country, and in the first millennium transition period from Bronze Age to Iron Age began. In that period in Azerbaijan there were appeared several branches of metallurgy treatment.
Jewelries, daggers, arms, copper products and other samples of art have been treated so refined, that in nowadays they are protected as very valuable exhibits in famous museums in such cities, as Paris, London, Brussels, Istanbul, Tehran and other cities.

Works of art, made from metal, for their content and their form are divided into two major groups:

1) Products of art;

2) Household goods.

Household equipment, works of art, agriculture instruments, that made by Ganja crafts, have been executed into two main technical methods:

\section{1) Casting}

2) Forging

Made of precious metals gold and silver jewelries, that prepared by Ganja masters, are divided into 4 groups for wearing and putting:

1) Neck jewelries - it is included such kind of jewelries, that gold piece coin, imperial, cardamom or barley, "iyirmibeshlik" (25), "medallions", "bogazaltı" (woman jewelries in ribbon form), bracelets, different kinds of beads and etc.

2) Jewelries for arms and fingers - this group include bracelets, bangles and rings with various precious stones as (turquoise, rubies, pearls and etc.).

3) Head jewelries - skull-cap and others.

4) Jewelries for clothiers [13].

In the first half of the XVIII-XIX centuries, as well as in other parts of Azerbaijan, in Ganja household objects, forging weapons and jewelries that made from metal were decorated with 6 technical ways.

1. Tattooing.

2.”Basma “(Pushing)

3."Karasavad"

4. Ornament

5. "Khatemkarliq"

6. Mitering.

Manufactory trade, silkworm breeding, saddle-making: In traditional production of cloth manufactory trade historically played an important place. This kind of craft that developed on the basis of local raw materials was tied with cotton-growing economy. Since the time of the early Middle Ages, Ganja as Tabriz, Ordubad have been the main center of Azerbaijan in production of cotton cloth.

In this ancient city printed cotton and calico fabrics have been widely produced. In traditional cloth productions the main place took the urban mines. In the early 30s of the XIX century in Ganja there were more than 164 people - weaving. The majority of these artists were weaving. In Ganja, which was the most important center of cloth production were produced different kinds of cotton cloth.

Weaving and dying: As in many places, production of wool, cotton and silk in and around Ganja made necessary emergence and development 
of weaving .Becoming weaving one of the ancient spheres of crafts in and around Ganja was connected with the rich raw material base here.

Presence of useful plant species for textile, including cotton, high level development of wool area of agriculture- sheep and goat breeding, camel breeding, horse breeding, presence of cotton cropping in Middle Ages and finally, regular expansion of silkworm breeding in this area created a foundation for growth of weaving here.

In addition, during the research work in Mingachevir, Kazakh, Shamakhi, Sargah, Pirsaat River Basin monuments there have been found whole and parts of weaving loom and different sizes of clay and bone samples that consist to weaving [14].

Mousey Kalankatly notes, that, along the banks of the Kura River ... there are a large amount of silk (mulberry tree) and cotton.
Arab author who lived in the $\mathrm{X}$ century AlIstaxri gives big information about, that in Barda in ownerless gardens were cultivated mulberry leaves and silkworm, then mulberry silk sent to Farsistan and Khusistan for sale.

His contemporary and fellow townsman Ibn Hovqal gives information about preparation of silk clothing from them.

Also, Al-Istakhri provides detailed information about cutting of textile in Derbend.

The art of Textile materials, that concern to weaving craft, consists of spindle heads and needles. The remnants of dying from the Shamkir, Ganja, Shatal and Khunan prove development of dying here. Plant remains have been widely used in dying.

\section{References:}

1. Guliyeva NM, Hasanov EL (2012) About ethnographic-archaeological research of some handicraft branches of Ganja during XIX - XX centuries. Progressive scientific explorations 2012: Proceedings of the 8th International scientific-practical conference. - Prague: Publishing House - Education and Science s.r.o., Prague, pp. 73-75

2. Ergenekon Cavidan (2005) Tempe keçe sanatında geleneksel süsleme üsulları ve günümüzde bu saneye yönelik yeni yaklaşımlar. Azərbaycan xalçası və xalq tətbiqi sənəti mövzusunda III Beynəlxalq simpoziumun materiallar1. Bakı: Elm, pp. 45-46

3. Ohmədov FM (2007) Gəncənin tarix yaddaş1. Gəncə: Elm.

4. Həsənov EL (2012) Gəncə İmamzadə türbəsi (tarixi-etnoqrafik tədqiqat). 1-ci nəşr. Bakı: Elm və təhsil, $268 \mathrm{p}$.

5. Guliyeva NM, Hasanov EL. (2012) New ethnographic approach to the research of main decorative - applied arts of Ganja of the XIX $\mathrm{XX}$ centuries. International scientific conference - Achievements in science: new views, problems, innovations. Lodz, pp. 56-58

6. Guliyeva NM, Hasanov EL (2012) Development of craft in Ganja in the beginning of XX century. Kadirbayevs readings - 2012: Proceedings of the 3rd archaeologic ethnographical scientific conference. Aktobe, pp. 415-417.

7. Kavkazskiy kalendar' na 1854 g. Tiflis, 1853. pp. 338-341.
8. Hasanov EL (2012) Die Gändschänischen teppiche von XIX - XX Jahrhundert als geschichtliche - ethnographische quelle. European Science and Technology (Die Europäische Wissenschaft und die Technologien): 2nd International scientific conference. Bildungszentrum Rdk e. V. Wiesbaden, pp. 26-27

9. Hasanov EL (2012) Innovational ethnographic facts on investigation and teaching of some basic decorative - applied arts of Ganja of the XIX - XX centuries. Applied and Fundamental Studies: Proceedings of the 1st International Academic Conference. - Saint Louis: Publishing House - Science and Innovation Center, Saint Louis, pp. 400-403

10. Azərbaycan arxeologiyası: (2008) 6 cilddə, VI cild. Bak1: Şərq-Qərb nəşriyyatı, 632 p.

11. Kulieva NM, Hasanov EL (2011) O razvitii khudozhestvennoy keramiki v drevney Gyandzhe. Materialy mezhdunarodnoy zaochnoy nauchno-prakticheskoy konferentsii Voprosy obshchestvennykh nauk: sotsiologiya, politologiya, filosofiya, istoriya. Novosibirsk: Apriori, pp. 132 - 135

12. Azərbaycan etnoqrafiyası (2007): 3 cilddə, I cild, Bak1: Şərq-Qərb, 544 p.

13. Hasanov EL (2012) Typical ethnographic features of traditional craft of Ganja in the end of XIX - beginning of XX centuries / Scientific potential of the World - 2012: Proceedings of the 8th International scientific - practical conference. - Sofia, pp. 23-24. 


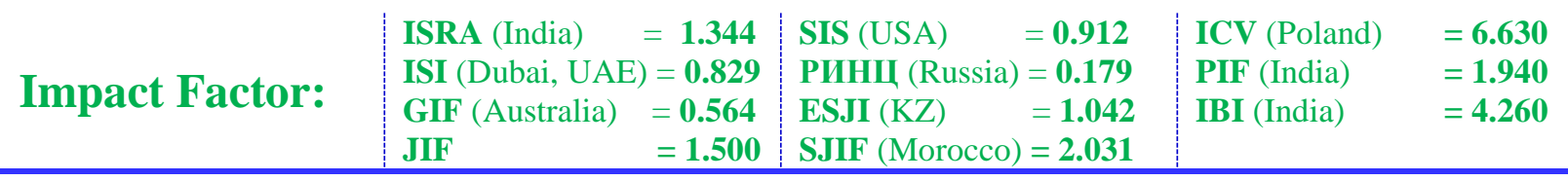

14. Alieva AS (1973) Vorsovye kovry Azerbaydzhana XIX - nach. XX vekov. Baku: Elm, pp. 21-25

15. The dawn of Art (1974) Leningrad: Aurora Art Publishers, $196 \mathrm{p}$.

16. Burton-Brown $\mathrm{T}$ (1951) Excavations in Azerbaijan, 1948. London, 250 p.

17. Guliyeva NM Hasanov EL (2013) Investigation of basic decorative-applied arts of Ganja on the basis of some innovative arguments and technologies. Science and Society: Proceedings of the 3rd International scientific-practical conference. London, pp. 281-291.

18. Ofəndiyev RS (1976) Azərbaycanın dekorativtətbiqi sənətləri. Bakı: İşıq.

19. Hasanov EL (2015) Multidisciplinary approach to investigation of the basic handicraft branches of Ganja till the XX century. ISJ Theoretical \& Applied Science 1(21): 7-15. DOI: http://dx.doi.org/10.15863/TAS.2015.01.21.2

20. Hasanov EL (2015) To the Question on Research of Craftsmanship Traditions of Ganja of XIX - First Half of XX Centuries. Mediterranean Journal of Social Sciences, vol.
6, № 1, Part S1, pp. 433-437. Doi:10.5901/mjss.2015.v6n1s1p433

21. Həmidova I (2000) Azərbaycan parça sənətinin tarixi inkişaf yolları. Elmi axtarışlar, VIII toplu, Bak1.

22. Həsənov EL (2015) Gəncə İmamzadə türbəsi ənənəvi multikulturalizm abidəsi kimi. Qafqazda mədəni-dini irsin qorunması mövzusunda beynəlxalq konfransın materialları. Bak1, 2015, pp. 117-120.

23. Həvilov HA (1991) Azərbaycan etnoqrafiyası. Bakı: Elm.

24. Gasanov EL (2015) Ob innovatsionnykh rezul'tatakh istoriko-etnograficheskogo issledovaniya khudozhestvennoy keramiki drevney Gyandzhi. Novyy universitet Aktual'nye problemy gumanitarnykh i obshchestvennykh nauk. № 8-9 (53-54). DOI: 10.15350/2222-1484.2015.8-9

25. Məmmədov FN (1976) XIX əsrdə Gəncə şəhərinin ərazisi, əhalisi və idarəsi (1868-ci ilə qədər). Azərbaycan SSR Elmlər Akademiyasının Xəbərləri (Tarix, fəlsəfə və hüquq seriyas1), №3, pp. 30-37. 